\title{
Corrigendum: The Generation of Mouse and Human Huntington Disease iPS Cells Suitable for In vitro Studies on Huntingtin Function
}

\author{
Wojciech J. Szlachcic ${ }^{1}$, Kalina Wiatr ${ }^{1}$, Marta Trzeciak ${ }^{1}$, Marek Figlerowicz ${ }^{2}$ and \\ Maciej Figiel ${ }^{\text {* }}$
}

${ }^{1}$ Department of Molecular Neurobiology, Institute of Bioorganic Chemistry, Polish Academy of Sciences, Poznań, Poland, ${ }^{2}$ Department of Molecular and Systems Biology, Institute of Bioorganic Chemistry, Polish Academy of Sciences, Poznań, Poland

Keywords: Huntington disease, iPS cells, NS cells, YAC128, shRNA, huntingtin, p53, juvenile HD

\section{A corrigendum on}

The Generation of Mouse and Human Huntington Disease iPS Cells Suitable for In vitro Studies on Huntingtin Function

by Szlachcic, W. J., Wiatr, K., Trzeciak, M., Figlerowicz, M., and Figiel, M. (2017). Front. Mol. Neurosci. 10:253. doi: 10.3389/fnmol.2017.00253

In the original article, in the Acknowledgments section there was a missing sentence with acknowledgments for Pawel M. Switonski. The authors apologize for this error and state that this does not change the scientific conclusions of the article in any way.

The following sentence was missing from the Acknowledgments section: "We kindly thank Pawel M. Switonski for his contribution to designing the psiOrange constructs." Therefore, the Acknowledgments section should have read as follows.

\section{OPEN ACCESS}

Edited and reviewed by:

Clevio Nobrega

University of Algarve, Portugal

*Correspondence:

Maciej Figiel

mfigie@@ibch.poznan.p

Received: 04 September 2017 Accepted: 15 September 2017

Published: 28 September 2017

Citation:

Szlachcic WJ, Wiatr K, Trzeciak M, Figlerowicz M and Figiel M (2017)

Corrigendum: The Generation of

Mouse and Human Huntington

Disease iPS Cells Suitable for In vitro

Studies on Huntingtin Function.

Front. Mol. Neurosci. 10:312.

doi: 10.3389/fnmol.2017.00312

\section{ACKNOWLEDGMENTS}

We thank Professor Allan Bradley (Wellcome Trust Sanger Institute, Cambridge, UK) for kindly providing the piggyBac reprogramming system. We kindly thank Pawel M. Switonski for his contribution to designing the psiOrange constructs. We thank Professor Jerzy Ciesiołka for kindly providing DO-1 antibody. The MW1 (developed by P. H. Patterson), 6G7 (developed by W. M. Halfter) and Rat-401 (developed by S. Hockfield) antibodies were obtained from the Developmental Studies Hybridoma Bank, created by the NICHD of the NIH and maintained at The University of Iowa, Department of Biology, Iowa City, IA, USA. 4-19 antibody was obtained from CHDI Foundation Repository at Corriel Institute Cell Repositories, Camden, NJ, USA. Confocal images were obtained in the Laboratory of Subcellular Structures Analysis, IBCh, PAS, Poland. Cell cultures were conducted in Cell and Tissue Culture Laboratory, IBCh, PAS, Poland.

Conflict of Interest Statement: The authors declare that the research was conducted in the absence of any commercial or financial relationships that could be construed as a potential conflict of interest.

Copyright $(0) 2017$ Szlachcic, Wiatr, Trzeciak, Figlerowicz and Figiel. This is an open-access article distributed under the terms of the Creative Commons Attribution License (CC BY). The use, distribution or reproduction in other forums is permitted, provided the original author(s) or licensor are credited and that the original publication in this journal is cited, in accordance with accepted academic practice. No use, distribution or reproduction is permitted which does not comply with these terms. 